\title{
Chapter 6. Statewide Red-Skinned Potato Variety Trials, 20061
}

\section{C.M. Hutchinson and Doug Gergela ${ }^{2}$}

General Comments: A goal of the statewide potato variety trial is to identify advanced potato selections for

Florida production. Established varieties were included to provide a baseline for comparison.

\section{Planting Information}

\begin{tabular}{|l|l|}
\hline $\begin{array}{l}\text { Florida Statewide Red } \\
\text { Potato Trial (Tables 15 and 16). }\end{array}$ & $\begin{array}{l}\text { PSREU - Hastings Farm (PSREU), One Site in Bunnell and One Site in } \\
\text { Hastings }\end{array}$ \\
\hline Planting Dates & PSREU (2/1/06), Bunnell (1/25/06), Hastings (1/26/06) \\
\hline Harvest Dates & PSREU (5/18/06), Bunnell (5/9/06), Hastings (5/8/06) \\
\hline Season Length & PSREU (86), Bunnell (104), Hastings (102) \\
\hline Fertilizer Program & $\begin{array}{l}\text { Grower standard practices for all sites except PSREU, which is similar to the } \\
\text { Red Variety Trial (Chapter 4). }\end{array}$ \\
\hline Irrigation Program & Seepage at all sites. \\
\hline
\end{tabular}

Experimental Design

\begin{tabular}{|l|l|}
\hline Number of Sites & 3 \\
\hline Number of Selections & 8 \\
\hline Within Row Spacing & 8 in $(20.3 \mathrm{~cm})$ \\
\hline Between Row Spacing & $38-42$ in $(96.5-106.6 \mathrm{~cm})$ \\
\hline Replications & 4 at each site \\
\hline Plot Size & $16 \mathrm{ft}(4.9 \mathrm{~m})$ single row \\
\hline
\end{tabular}

Production Statistics- Based over all sites

Highest Total Yield

Highest Marketable Yield

Red LaSoda (422 cwt/acre or $47.3 \mathrm{MT} / \mathrm{ha}$ )

Red LaSoda 13 (374 cwt/acre or $41.9 \mathrm{MT} / \mathrm{ha})$

1. This document is HS1090, one of a series of the Horticultural Sciences Department, Florida Cooperative Extension Service, Institute of Food and Agricultural Sciences, University of Florida. Original publication date March 21, 2007. Visit the EDIS Web Site at http://edis.ifas.ufl.edu.

2. Chad M. Hutchinson, Associate professor, Doug Gergela, Sr. Bilogical Scientist, Horticultural Sciences Department, Cooperative Extension Service, Institute of Food and Agricultural Sciences, University of Florida, Gainesville, 32611.

The use of trade names in this publication is solely for the purpose of providing specific information. UF/IFAS does not guarantee or warranty the products named, and references to them in this publication does not signify our approval to the exclusion of other products of suitable composition. All chemicals should be used in accordance with directions on the manufacturer's label. Use pesticides safely. Read and follow directions on the manufacturer's label.

The Institute of Food and Agricultural Sciences (IFAS) is an Equal Opportunity Institution authorized to provide research, educational information and other services only to individuals and institutions that function with non-discrimination with respect to race, creed, color, religion, age, disability, sex, sexual orientation, marital status, national origin, political opinions or affiliations. U.S. Department of Agriculture, Cooperative Extension Service, University of Florida, IFAS, Florida A. \& M. University Cooperative Extension Program, and Boards of County Commissioners Cooperating. Larry Arrington, Dean 
ஸे

高

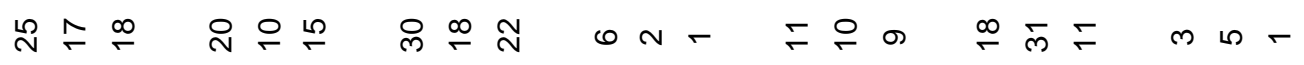

焉

尺)

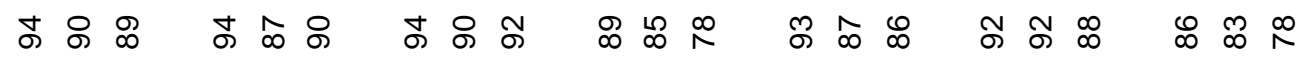

$\overline{4}$

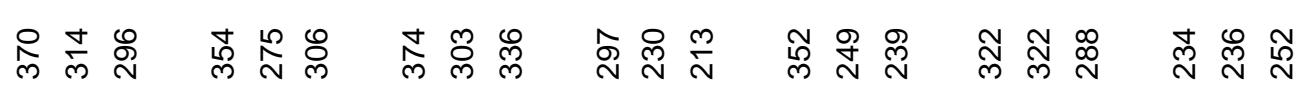

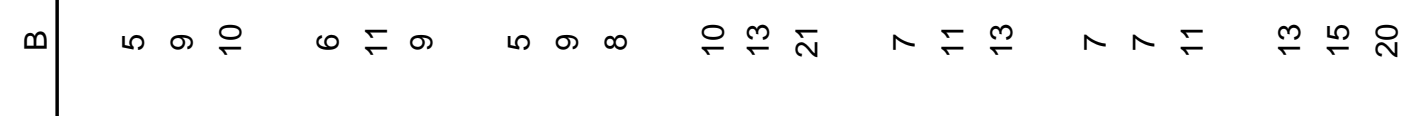

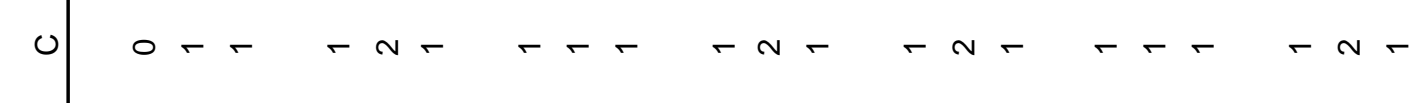




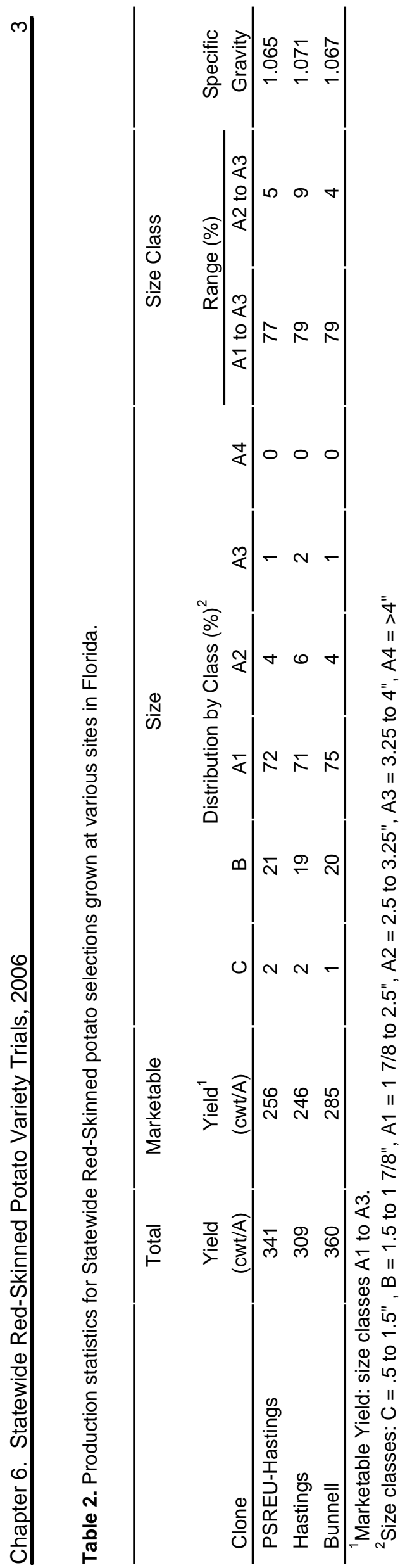




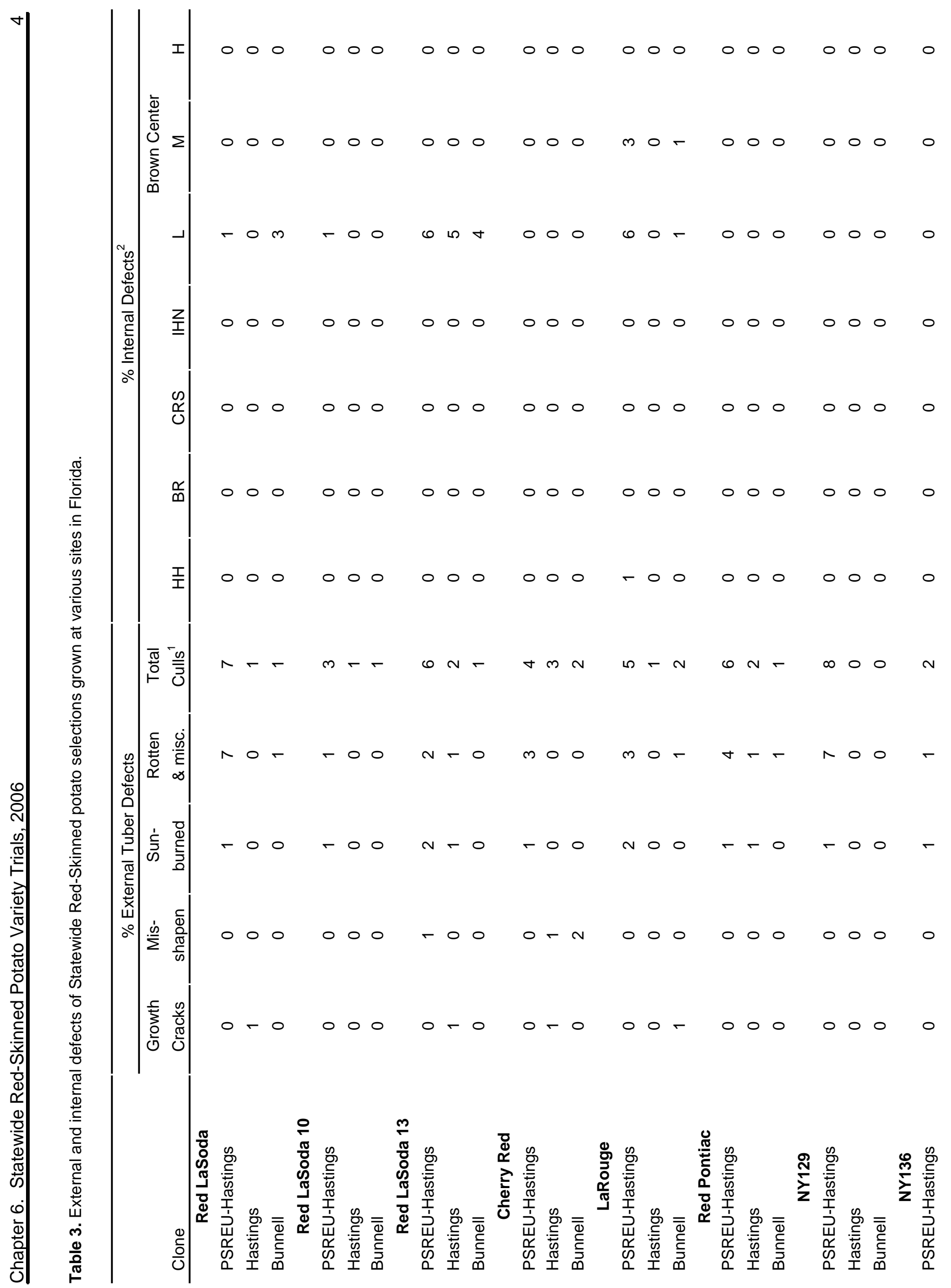




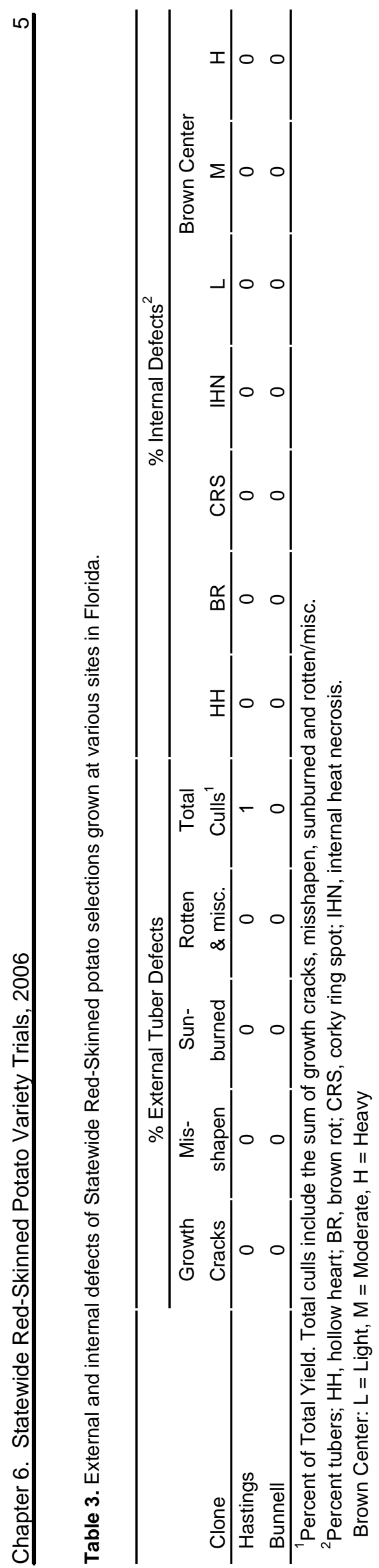

